\title{
PENGEMBANGAN PERANGKAT PEMBELAJARAN DENGAN MENGGUNAKAN STRATEGI POE PADA MATERI POKOK ASAM BASA UNTUK MENINGKATKAN HASIL BELAJAR PESERTA DIDIK
}

\author{
Sri Agustiani Basir, Muharram ${ }^{1}$, Muhammad Danial ${ }^{3}$ \\ ${ }^{1,2}$ Dosen Program Pascasarjana Universitas Negeri Makassar \\ Email: icp.sriagustianibasir@gmail.com
}

\begin{abstract}
ABSTRAK
Tujuan penelitian ini adalah untuk memperoleh gambaran proses pengembangan dan memperoleh kemasan perangkat pembelajaran dengan menggunakan strategi POE yang valid, praktis dan efektif pada materi pokok asam basa untuk meningkatkan hasil belajar peserta didik. Produk pengembangan perangkat pembelajaran dengan menggunakan strategi POE pada materi pokok asam basa yang diujicobakan di SMA Negeri 1 Bulukumba berpedoman pada langkah-langkah pokok pengembangan pembelajaran model 4-D yang terbagi dalam empat tahapan yaitu: pendefenisian (define), perancangan (design), pengembangan (develop), dan penyebaran (disseminate). Perangkat pembelajaran yang dikembangkan meliputi: rencana pelaksanaan pembelajaran (RPP), buku peserta didik (BPD), lembar kegiatan peserta didik (LKPD), dan tes hasil belajar (THB). Data kevalidan diperoleh berdasarkan penilaian validator terhadap perangkat pembelajaran dan hasil kevalidan berada pada kategori "valid". Data keefektifan yang diperoleh berdasarkan hasil belajar peserta didik yang memiliki ratarata 80,00 dari skor ideal 100 dengan peserta tuntas belajar 30 orang atau sebesar 85,00\%, dan data respon peserta didik yang memberikan respon positif terhadap perangkat pembelajaran yang digunakan. Serta data kepraktisan diperoleh berdasarkan keterlaksanaan seluruh pembelajaran. Data menunjukkan bahwa memenuhi kriteria valid, efektif dan praktis.
\end{abstract}

Kata kunci: Kata kunci: Strategi POE, model 4-D, hasil belajar

\begin{abstract}
The study aims at discovering the description of development process and package of learning device using POE strategy which is valid, practical, and effective in Acid Base material to improve the students' learning outcomes. The product of learning device development using POE strategy in Acid Base material was tested in SMAN 1 Bulukumba which referred to 4-D model learning development steps that consisted of four steps, namely defining, design, development, and dissemination. The learning device developed covered: lesson plan, student's textbook, student's work sheet, and learning test. Data validity was obtained based on the assessment by assessors on learning device and the validity result was in the "valid" category. Data effectiveness was obtained based on students' learning outcomes who has an average of 80.00 from the ideal score of 100 with a complete participant learns 30 people or equal to $85.00 \%$, and students' response who provide responded positively to the learning device used. And data practically was obtained based on implementation of all learning. The result of the study reveals that the learning device has met valid, effective, and practical criteria.
\end{abstract}

Keywords: POE strategy, 4-D model, learning outcomes 


\section{PENDAHULUAN}

Pendidikan mempunyai arti usaha untuk menumbuh kembangkan potensi sumber daya manusia melalui kegiatan pembelajaran. Upaya peningkatan kualitas pendidikan di Indonesia ditandai dengan adanya penyempurnaan-penyempurnaan yang dilaksanakan oleh pemerintah pada setiap aspek pendidikan. Selain dengan penyediaan dana pendidikan yang begitu besar, berbagai upaya lain juga telah ditempuh dalam meningkatkan kualitas pendidikan, antara lain: pengembangan model dan strategi pembelajaran, diadakannya penataran bagi pendidik, distribusi pendidik secara baik, perbaikan sarana dan prasarana pendidikan, serta pembaharuan kurikulum. Pembaharuan kurikulum yang dilakukan oleh pemerintah dari KBK menjadi KTSP, bahkan saat ini telah diterapkan kurikulum 2013 (Yupani, et al, 2013).

Pengembangan kurikulum 2013 didasarkan pada beberapa faktor eksternal antara lain: arus globalisasi, kemajuan teknologi dan informasi, kebangkitan industri kreatif dan budaya, dan perkembangan pendidikan di tingkat international. Keikutsertaan Indonesia di dalam studi International Trends in International Mathematics and Science Study (TIMSS) dan Program for International Student Assessment (PISA) sejak tahun 1999 juga menunjukkan bahwa capaian anak-anak Indonesia tidak menggembirakan dalam beberapa kali laporan yang dikeluarkan TIMSS dan PISA (OECD, 2013). Hal ini disebabkan oleh antara lain banyaknya materi uji yang ditanyakan di TIMSS dan PISA tidak terdapat dalam kurikulum Indonesia, sehingga dilakukan penyempurnaan kurikulum.

Pembaharuan kurikulum menuntut seorang pendidik untuk mengembangkan pembelajaran seperti pengembangan silabus dan RPP. Namun demikian, fakta menunjukkan bahwa dalam kegiatan pembelajaran di kelas, pendidik masih lebih banyak menggunakan sumber belajar tunggal berupa buku ajar yang dipegang peserta didik dan hanya menggunakan LKPD yang berisi sekumpulan pertanyaan (Warpala, et al, 2010). Fenomena ini disebabkan oleh terbatasnya kemampuan yang dimiliki oleh pendidik seperti kurangnya kemampuan pendidik untuk mengemas bahan ajar, banyak pendidik yang tidak menggunakan media, kurang pahamnya pendidik terhadap sumbersumber bahan ajar, serta kurangnya kemampuan pendidik untuk menerapkan strategi pembelajaran yang inovatif.

Strategi pembelajaran memiliki peranan yang penting dan merupakan salah satu penunjang utama keberhasilan seorang pendidik dalam mengajar. Strategi pembelajaran yang dipakai oleh pendidik akan berpengaruh terhadap cara belajar peserta didik.

Pembelajaran adalah upaya yang dilakukan oleh pendidik agar terjadi proses belajar pada peserta didik. Keberhasilan dalam proses pembelajaran tercapai ketika adanya perubahan perilaku atau pola pikir peserta didik yang diinginkan. (Rusman, 2011).

Untuk mengatasi masalah dalam proses pembelajaran tersebut, maka pendidik harus mampu menciptakan variasi strategi pembelajaran yang dapat membuat peserta didik aktif, dapat meningkatkan aktivitas dan prestasi belajar peserta didik melalui pemilihan dan penggunaan strategi pembelajaran yang tepat. Aktivitas belajar adalah segala tingkah laku peserta didik pada saat mengikuti kegiatan pembelajaran baik yang bersifat fisik maupun mental.

Ilmu kimia merupakan bagian dari sains atau Ilmu Pengetahuan Alam yang meliputi banyak konsep seperti Asam Basa. Ilmu kimia merupakan ilmu yang diperoleh dan dikembangkan berdasarkan eksperimen yang mencari jawaban atas pertanyaan apa, mengapa dan bagaimana yang diharapkan mampu menampilkan proses sains dalam diri peserta didik. Satu kata kunci untuk pembelajaran kimia adalah pembelajaran kimia harus melibatkan peserta didik secara aktif untuk berinteraksi dengan objek 
konkret, sehingga peserta didik tidak hanya sekedar menguasai materi dengan cara menghafal, tanpa memahami maknanya sehingga berpengaruh terhadap kemampuan berpikir peserta didik sehingga dapat meningkatkan hasil belajar peserta didik.

Hasil belajar adalah hasil yang dicapai peserta didik dalam bentuk angkaangka atau skor setelah pendidik memberikan tes hasil belajar pada setiap akhir pembelajaran. Nilai yang diperoleh peserta didik inilah kemudian akan dijadikan acuan untuk melihat penguasaan peserta didik dalam menerima materi pelajaran (Dimyati, 2006).

Berdasarkan hasil observasi yang dilakukan pada peserta didik kelas XI IPA SMA 1 Bulukumba, salah satu masalah yang dihadapi pendidik sekarang, yaitu rendahnya aktivitas belajar peserta didik pada proses pembelajaran terkhusus pada materi pokok asam basa. Aktivitas peserta didik sebagian besar hanya mendengar, menulis (mencatat) penjelasan pendidik, dan latihan soal yang diberikan oleh pendidik sehingga hasil belajar yang diperoleh peserta didik pada materi pokok asam basa rendah dimana tingkat kelulusan hanya $65 \%$. Hal ini belum memenuhi standar ketuntatan kelas yaitu $80 \%$ dari jumlah peserta didik. Adapun standar kelulusan berdasarkan Kriteria Ketuntasan Minimal (KKM), yaitu 75.

Berdasarkan permasalahan di atas, maka dibutuhkan strategi pembelajaran yang dapat merangsang peserta didik untuk lebih aktif, sehingga peserta didik tidak hanya mendengar dan mencatat penjelasan pendidik, serta menjawab soal, tetapi juga mampu mengajukan pertanyaan, menyampaikan pendapat/gagasan, menyimpulkan dan mengkomunikasikan pesan pelajaran baik dalam kelompok maupun dalam kelas. Ada banyak strategi pembelajaran aktif yang dapat membuat peserta didik lebih aktif dalam mengikuti pembelajaran, salah satunya yaitu PredictObserve-Explain (POE) (Ipek, 2010).

Strategi pembelajaran PredictObserve-Explain adalah sebuah strategi pembelajaran yang menguji pemahaman dengan mengharuskan peserta didik untuk melaksanakan tiga tugas yaitu (1) Prediction merupakan suatu proses membuat dugaan terhadap suatu peristiwa, (2) Observation yaitu melakukan pengamatan apa yang terjadi. Dengan kata lain peserta didik diajak untuk melakukan percobaan, untuk menguji kebenaran prediksi peserta didik dan (3) Explanation yaitu pemberian penjelasan tentang kesesuaian antara tahap observasi dengan dugaan hasil eksperimen dan membentuk struktur kognitif peserta didik menjadi lebih baik, karena kegiatan-kegiatan dalam strategi ini memberikan kesempatan pada peserta didik untuk belajar secara konkret (Warsono \& Hariyanto, 2012).

Landasan filosofis dari strategi POE adalah teori pembelajaran konstruktivis (White dan Gunstone dalam Karamustafaoğlu \& Mamlok-naaman, 2015). Teori ini mempertimbangkan bahwa pemahaman peserta didik di awal pembelajaran harus dipertimbangkan ketika mengembangkan rencana pembelajaran.

Penelitian yang relevan dengan penelitian ini yaitu penelitian yang dilakukan oleh Farhana Iqbalia (2016), yang berpendapat bahwa terdapat pengaruh signifikan strategi pembelajaran POE terhadap hasil belajar peserta didik. Hal ini juga dapat dilihat dalam penelitian Kibirige, et al. (2014) dan Karamustafaoğlu dan Mamlok-naaman (2015) menyatakan bahwa, penggunaan strategi POE memiliki pengaruh positif terhadap hasil belajar peserta didik.

Berdasarkan latar belakang yang telah diuraikan, maka penulis melakukan penelitian pengembangan perangkat pembelajaran dengan menggunakan POE pada materi pokok asam basa untuk meningkatkan hasil belajar peserta didik. Dalam mengembangkan perangkat pembelajaran diperlukan sebuah model pengembangan. Model pengembangan yang akan digunakan dalam penelitian ini adalah model pengembangan 4D dari Thiagarajan yang terdiri dari empat tahap, yaitu 
pendefinisian (define), perancangan (design), pengembangan (develop) dan penyebaran (dessimenate) dengan pertimbangan bahwa model pengembangan 4D sangat cocok digunakan pada pengembangan perangkat pembelajaran karena tahapan-tahapan dalam model ini urutan langkahnya sederhana, sehingga memudahkan peneliti dalam mengembangkan perangkat. Kemudahan dalam keempat tahapannya yang dimulai dari tahap pendefinisian sampai tahap penyebaran yang urutan-urutan langkah dalam setiap tahap tersebut sudah ditentukan; dalam tahap pengembangan melibatkan penilaian ahli, sehingga sebelum dilakukan uji coba di lapangan, perangkat pembelajaran tersebut telah mengalami revisi berdasarkan penilaian, saran dan masukan para ahli.

\section{METODE PENELITIAN}

\section{Jenis Penelitian}

Penelitian ini adalah penelitian pengembangan atau Research and Development ( $\mathrm{R} \& \mathrm{D})$ yang bertujuan untuk mengembangkan dan memperoleh perangkat pembelajaran berbasis POE pada materi pokok asam basa untuk meningkatkan hasil belajar peserta didik.

\section{Waktu dan Tempat Penelitian}

Penelitian dilaksanakan di SMAN 1 Bulukumba Tahun Pelajaran 2016/2017.

\section{Subjek Penelitian}

Subjek penelitian merupakan peserta didik kelas XI IPA 1 dengan jumlah siswa 35 orang sebagai kelas eksperimen dan kelas XI IPA 3 dengan jumlah siswa 31 sebagai kelas kontrol pada semester genap tahun ajaran 2016/2017.

\section{Definisi Operasional}

Ada beberapa definisi operasional yang digunakan untuk memperoleh data dalam penelitian ini, antara lain:
1. Perangkat pembelajaran adalah sekumpulan sumber/alat yang menunjang terlaksananya pembelajaran

dengan baik. Perangkat pembelajaran dalam penelitian ini adalah Rencana Pelaksanaan Pembelajaran (RPP), Lembar Kegiatan Peserta Didik (LKPD), Buku Peserta Didik (BPD), dan Tes Hasil Belajar (THB)

2. Pengembangan perangkat pembelajaran adalah serangkaian proses atau kegiatan yang dilakukan untuk menghasilkan sebuah perangkat pembelajaran berdasarkan teori pengembangan yang telah ada dengan menggunakan model pengembangan 4D oleh Thiagarajan.

3. Pengembangan perangkat pembelajaran dengan menggunakan strategi POE adalah rancangan suatu kegiatan pembelajaran yang menggunakan 3 kegiatan yaitu: predict, observe, dan explain untuk meningkatkan hasil belajar peserta didik.

4. Hasil belajar adalah nilai hasil belajar kognitif siswa yang diperoleh siswa setelah pembelajaran kimia dengan menggunakan strategi POE.

\section{Data, Instrumen, dan Teknik Pengumpulan Data}

Data yang diperoleh dari penelitian ini berupa data hasil validasi oleh validator ahli, hasil pengerjaan soal tes kognitif, data observasi keterlaksanaan pembelajaran, dan angket respon peserta didik.

Instrumen penelitian yang digunakan yaitu lembar validasi, soal tes kemampuan awal, soal pretest dan posttest, lembar observasi keterlaksanaan pembelajaran, dan angket respon peserta didik.

Lembar validasi diberikan kepada dosen sebagai validator ahli untuk mengetahui kelayakan perangkat pembelajaran dan mendapatkan saran untuk perbaikan. Kegiatan tes berupa tes kemampuan awal, pretest sebelum pembelajaran awal dimulai dan posttest setelah akhir dari semua pembelajaran. Kegiatan dengan lembar keterlaksanaan pembelajaran dilakukan oleh observer, dan angket respon diberikan pada peserta didik. 


\section{Teknik Analisis Data}

Berikut ini dikemukakan tentang analisis data kevalidan, kepraktisan, dan keefektifan (Hobri, 2009).

\section{Analisis Data Kevalidan Perangkat Pembelajaran}

Adapun kegiatan yang dilakukan dalam proses analisis data kevalidan perangkat pembelajaran yang meliputi Rencana Pelaksanaan Pembelajaran (RPP) Buku Peserta Didik (BPD), Lembar Kegiatan Peserta Didik (LKPD), dan Tes Hasil belajar (THB) yang digunakan yaitu: Menentukan kategori validitas rata-rata $\bar{A} \iota$ atau rata-rata $\bar{X}$ dengan kategori validasi yang ditetapkan, sebagai berikut (Nurdin, 2007):

$3,5 \leq M \leq 4 \quad$ sangat valid

$2,5 \leq \mathrm{M}<3,5$ valid

$1,5 \leq \mathrm{M}<2,5$ cukup valid

M $<1,5$ tidak valid

$\mathrm{M}=\mathrm{Ai}$ untuk mencari validitas setiap aspek

$\mathrm{M}=\bar{X}$ untuk mencari validitas keseluruhan aspek

Kriteria yang digunakan untuk memutuskan bahwa perangkat pembelajaran memiliki derajat kevalidan yang memadai adalah nilai $\bar{X}$ untuk keseluruhan aspek minimal berada dalam kategori cukup valid dan nilai $\overline{A l}$ untuk setiap aspek minimal berada dalam kategori valid. Jika tidak demikian, maka perlu dilakukan revisi berdasarkan saran dari validator atau dengan melihat kembali aspek-aspek yang nilainya kurang selanjutnya dilakukan validasi ulang lalu dianalisis kembali.

Selanjutnya dihitung reliabilitas penilaian perangkat pembelajaran dengan menggunakan rumus percentage of agreements Grinnell (Hobri, 2009).

$R=\frac{\operatorname{Agreements}(A)}{\text { Disagreements }(D)+\operatorname{Agreements}(A)} \times 100 \%$

Keterangan :

$\mathrm{A}=$ besarnya frekuensi kecocokan antara data dua pengamat
$\mathrm{D}=$ besarnya frekuensi tidak cocok antara data dua pengamat

$\mathrm{R}=$ koefisien (derajat) reliabilitas instrument

Kriteria lembar pengamatan perangkat pembelajaran dikatakan reliabel jika nilai reliabilitasnya $\mathrm{R} \geq 0.75$ ( Hobri, 2009).

\section{Analisis Data Kepraktisan} Perangkat Pembelajaran Berbasis POE

Proses analisis kepraktisan perangkat pembelajaran adalah mencari rata-rata hasil pengamatan dua observer untuk setiap aspek $(\overline{A \imath})$, setiap kriteria $(\overline{K \iota})$, dan rata-rata $(\bar{X})$, selanjutnya menentukan kategori keterlaksanaan setiap aspek atau keseluruhan aspek keterlaksanaan perangkat pembelajaran sebagai berikut (Nurdin, 2007):

$1.5 \leq \mathrm{M} \leq 2.0 \quad$ terlaksana seluruhnya

$0.5 \leq \mathrm{M}<1.5$ terlaksana sebagian

$0.0 \leq \mathrm{M}<0.5$ tidak terlaksana

Keterangan:

$M=\overline{A_{i}}$ untuk mencari keterlaksanaan setiap aspek

$M=\bar{X}$ untuk mencari keterlaksanaan keseluruhan aspek.

Kriteria yang digunakan untuk memutuskan bahwa perangkat pembelajaran memiliki derajat keterlaksanaan yang memadai adalah nilai $\bar{X}$ minimal berada dalam kategori terlaksana sebagian, berarti perangkat pembelajaran tidak direvisi. Apabila nilai $\bar{X}$ berada dalam kategori lainnya, maka perlu dilakukan revisi dengan melihat kembali pengamatan terhadap keterlaksanan hasil revisi, kemudian dianalisis kembali. Demikian seterusnya sampai memenuhi nilai $\bar{X}$ minimal berada dalam kategori terlaksana sebagian, maka perangkat yang dikembangkan dinyatakan praktis.

\section{Analisis Data Keefektifan Perangkat Pembelajaran}

Analisis data keefektifan strategi pembelajaran dengan menggunakan strategi POE dapat diketahui dari analisis data dari: 
a. Analisis Data Respon Peserta Didik terhadap Pembelajaran

Data respon peserta didik terhadap pembelajaran terbagi atas tiga aspek, yaitu: (1) respon peserta didik terhadap pelaksanaan pembelajaran, (2) respon peserta didik terhadap buku peserta didik dan LKPD. Kegiatan yang dilakukan untuk menganalisis data respon peserta didik dalam tiga aspek tersebut relatif sama, yakni melalui langkah-langkah sebagai berikut:

1) Menghitung banyaknya peserta didik yang memberi respon positif sesuai dengan aspek yang ditanyakan, kemudian menghitung persentasenya.

2) Menentukan kategori untuk respon positif peserta didik dengan cara mencocokkan hasil persentase dengan kriteria yang ditetapkan.

3) Jika hasil analisis menunjukkan bahwa respon peserta didik belum positif, maka dilakukan revisi terhadap perangkat yang telah dikembangkan.

Analisis untuk menghitung persentase banyaknya peserta didik yang memberi respon pada setiap kategori yang dinyatakan dalam lembar angket menggunakan rumus sebagai berikut:

$$
P R S=\frac{\sum A}{\sum B} \times 100 \%
$$

(Trianto, 2009)

Keterangan:

PRS = persentase banyak peserta didik yang memberi respon positif terhadap kategori yang ditanyakan.

$\sum A=$ banyaknya peserta didik yang memberi respon positif terhadap setiap kategori yang ditanyakan dalam angket.

$\sum B=$ banyaknya peserta didik yang menjadi subjek uji coba.

Sedangkan kriteria penilaiannya adalah sebagai berikut:

$80 \% \leq \mathrm{x} \leq 100 \%$ sangat merespon/sangat setuju (SS)

$60 \% \leq \mathrm{x}<80 \%$ merespon/setuju (S)

$40 \% \leq \mathrm{x}<60 \%$ netral/cukup setuju (CS)

$20 \% \leq \mathrm{x}<40 \%$ tidak merespon/ tidak setuju (TS)

$. x<20 \%$ sangat tidak merespon (STS)

(Riduwan, 2008)
Respon peserta didik dikatakan efektif jika sekurang-kurangnya $80 \%$ dari semua peserta didik menjawab sangat merespon (SS) atau merespon (S) atau ratarata akhir dari skor peserta didik minimal berada pada kategori merespon (S).

b. Analisis Data Respon Pendidik Dengan Menggunakan POE

Analisis data tentang respon pendidik terhadap srategi POE diperoleh dari angket respon pendidik terhadap strategi pembelajaran dan pelaksanaan pembelajaran. Selanjutnya dianalisis dengan persentase. Kegiatan yang dilakukan untuk menganalisis data respon pendidik yakni melalui langkah-langkah sebagai berikut:

1) Menghitung banyaknya respon pendidik yang memberi respon positif sesuai dengan aspek yang ditanyakan, kemudian menghitung persentasenya.

2) Menentukan kategori untuk respon positif pendidik dengan cara mencocokkan hasil persentase dengan kriteria yang ditetapkan.

3) Jika hasil analisis menunjukkan bahwa respon guru belum positif, maka dilakukan revisi terhadap perangkat yang telah dikembangkan.

Analisis untuk menghitung persentase banyaknya guru yang memberi respon pada setiap kategori yang dinyatakan dalam lembar angket.

Strategi pembelajaran dikatakan efektif jika sekurang-kurangnya $80 \%$ dari semua jawaban guru memberi respon sebagai berikut: sangat merespon (SS) atau merespon (S) atau rata-rata akhir dari skor guru minimal berada pada kategori merespon (S).

c. Analisis hasil belajar peserta didik

Analisis data untuk tes kemampuan awal dan tes hasil belajar peserta didik yaitu analisis tes kemampuan awal untuk mengetahui kemampuan awal peserta didik sebelum pembelajaran berbasis poe dibagi menjadi 3 kategori, yaitu kelompok untuk kemampuan awal rendah, sedang, dan tinggi. Nilai terendah 10 dan nilai tertinggi 
100. Berdasarkan nilai tersebut, maka pengkategorian dapat dilihat pada tabel 3.1 Tabel 1 Pengkategorian Kemampuan Awal

\begin{tabular}{|c|c|}
\hline Nilai Kemampuan Awal & Interpretasi \\
\hline $10-40$ & Rendah \\
\hline $41-70$ & Sedang \\
\hline $71-100$ & Tinggi \\
\hline
\end{tabular}

Analisis data hasil belajar bertujuan untuk mengetahui peningkatan hasil belajar peserta didik yang terjadi sesudah penggunaan startegi POE dengan menggunakan rumus gain ternormalisasi $(N$-gain) untuk melihat seberapa besar peningkatan hasil belajar peserta didik setelah diajarkan dengan menggunakan strategi POE sebagai berikut:

$$
\begin{aligned}
& g=\frac{S_{\text {post }}-S_{\text {pre }}}{S_{\text {maks }}-S_{\text {pre }}} \\
& \text { (Richard dalam Meltzer, } \\
& \text { 2002) }
\end{aligned}
$$

Keterangan:

$\mathrm{S}_{\text {pre }}=$ skor total pada tes awal

$\mathrm{S}_{\text {post }}=$ skor total pada test akhir

$\mathrm{S}_{\text {maks }}=$ Skor maksimum yang mungkin dicapai

Dengan menggunakan rumus $N$ Gain tersebut maka dapat diketahui seberapa besar peningkatan keterampilan proses sains peserta didik Kelas XI secara individu dan secara keseluruhan. Dengan kriteria tingkat $N$-Gain adalah sebagai berikut.

Tabel 2 Kategori Tingkat $N$-Gain

\begin{tabular}{|c|c|}
\hline Batasan & Kategori \\
\hline $\mathrm{g}>0,7$ & Tinggi \\
$0,3 \leq \mathrm{g} \leq 0,7$ & Sedang \\
$\mathrm{g}<0,3$ & Rendah \\
\hline
\end{tabular}

(Meltzer, 2002

Tabel 3 Kriteria Ketuntasan

\begin{tabular}{|c|c|}
\hline Nilai & Kriteria \\
\hline$\geq 75$ & Tuntas \\
\hline$<75$ & Tidak Tuntas \\
\hline
\end{tabular}

(Sumber: SMA Negeri 1 Bulukumba)

\section{HASIL DAN PEMBAHASAN}

Penelitian ini dilaksanakan di SMAN 1 Bulukumba dan subjek penelitian pada peserta didik kelas XI. Rincian hasil penelitian sebagai berikut.

\section{Tahap Define}

Penelitian pengembangan perangkat pembelajaran dengan menggunakan strategi POE pada materi asam basa untuk meningkatkan hasil belajar peserta didik.

2. Tahap Design

Perangkat pembelajaran yang dikembangkan meliputi RPP, LKPD, BPD, dan THB.

3. Tahap Develop

a. Validitas perangkat pembelajaran

Produk awal dari perangkat pembelajaran divalidasi oleh dua validator ahli. Adapun analisis instrument validasi terdapat pada tabel 4 .

\begin{tabular}{|c|c|c|}
\hline Perangkat & $\begin{array}{l}\text { Penilaian } \\
(\mathrm{X})\end{array}$ & Kategori \\
\hline RPP & 3,29 & $\mathrm{~V}$ \\
\hline LKPD & 3,60 & SV \\
\hline BPD & 3,17 & $\mathrm{~V}$ \\
\hline THB & 3,50 & $\mathrm{~V}$ \\
\hline $\begin{array}{l}\text { 1) Rencana } \\
\text { (RPP) }\end{array}$ & Pelaksanaan & Pembelajaran \\
\hline
\end{tabular}

Tabel 4. Deskripsi hasil penilaian ahli terhadap perangkat pembelajaran

Tabel 4 di atas menunjukkan bahwa nilai rata-rata setiap aspek dari RPP adalah 3,29 dan koefisien realibitas 0,75 atau $83,74 \% \quad(2,5 \leq \mathrm{M} \leq 3,5)$ berarti RPP tersebut memenuhi kategori valid dan reliabel. Secara keseluruhan aspek sudah memenuhi kriteria kevalidan.

2) Lembar Kerja Peserta Didik (LKPD)

Tabel 4 di atas menunjukkan bahwa nilai rata-rata setiap aspek dari LKPD adalah 3,60 dan koefisien realibitas 0,80 atau $80,00 \%(3,5 \leq \mathrm{M}<4)$ berarti LKPD tersebut memenuhi kategori sangat valid dan reliabel.

3) Buku Peserta Didik (BPD)

Tabel 4 di atas menunjukkan bahwa nilai rata-rata setiap aspek dari BPD adalah 3,17 dan koefisien realibitas 0,83 atau $83,33 \%(2,5 \leq \mathrm{M}<3,5)$ berarti BPD tersebut memenuhi kategori valid dan reliabel.

4) Tes Hasil Belajar (THB)

Tabel 4 di atas menunjukkan bahwa nilai rata-rata setiap aspek dari instrumen tes hasil belajar adalah 3,73 dan koefisien 
realibitas 0,85 atau $85,42 \%(3,5 \leq \mathrm{M} \leq 4)$ berarti THB tersebut memenuhi kategori sangat valid dan reliabel.

Hasil validasi perangkat
menunjukkan menunjukkan seluruh perangkat pembelajaran yang telah divalidasi berada pada kategori valid. Kevalidan perangkat pembelajaran tentunya mengalami beberapa kali revisi agar menghasilkan instrumen yang mampu mengukur tingkat kelayakan dari strategi pembelajaran POE ini. Perangkat pembelajaran layak untuk dipergunakan dalam pelaksanaan pembelajaran di sekolah jika mampu memperbaiki hasil belajar peserta didik.

b. Kepraktisan Perangkat Pembelajaran

Dari hasil uji pengembangan diperoleh hasil nilai rata-rata di kelas XI IPA 1 sebesar 1,89 dengan reliabilitas 91,66\%. Berdasarkan kriteria yang telah diuraikan sebelumnya disimpulkan bahwa nilai rata-rata tersebut berada pada kategori terlaksana seluruhnya. Dengan demikian bahwa implementasi perangkat pembelajaran yang telah dikembangkan perangkat pembelajarannya melalui instrumen keterlaksanaan perangkat pembelajaran telah memenuhi syarat kepraktisan.

c. Keefektivan Perangkat

Keefektifan dari perangkat pembelajaran dengan menggunakan strategi POE yang telah dikembangkan perangkat pembelajarannya berdasarkan kriteria yang telah disebutkan sebelumnya, suatu perangkat pembelajaran dikatakan efektif apabila memenuhi syarat:

1) Respon peserta didik terhadap perangkat pembelajaran dengan menggunakan strategi POE minimal dalam kategori positif

2) Peserta didik berhasil dalam belajar apabila persentasi ketuntasan mencapai $80 \%$ dengan standar nilai 75 dengan skor maksimal 100. Pencapaian tersebut dinilai peserta didik telah mencapai kompetensi.

Tabel. 5 Rangkuman Hasil Uji N-Gain Skor Kelas XI IPA 1

\begin{tabular}{|l|c|c|}
\hline \multirow{2}{*}{$\begin{array}{c}\text { Kategori N- } \\
\text { Gain }\end{array}$} & \multicolumn{2}{|c|}{ Peserta didik } \\
\cline { 2 - 3 } & Jumlah & Persentase \\
\hline Tinggi & 22 & 62,86 \\
\hline Sedang & 4 & 11,43 \\
\hline Rendah & 9 & 25,71 \\
\hline
\end{tabular}

Peningkatan kemampuan peserta didik dalam belajar kimia dapat dilihat dengan menggunakan analisis uji N-Gain. Dari hasil uji N-Gain menunjukkan bahwa pada kelas XI IPA 1 nilai rata-rata $\mathrm{N}$ Gainnya 0,8 pada kategori tinggi. Selain itu, dari uji N-Gain terlihat bahwa pada kelas XI IPA 1 terdapat 30 peserta didik tuntas dan 5 peserta didik tidak tuntas. Peserta didik dikatakan tuntas jika mengalami peningkatan hasil belajar kimia $>75 \%$.

4. Tahap Disseminate

Perangkat yang dihasilkan pada tahap akhir pengembangan, selanjutnya disebarkan atau disosialisasikan secara terbatas pada guru kimia yang berada di SMAN 1 Bulukumba. Dari dua guru kimia yang diberikan lembar persepsi penyebaran, umumnya menyimpulkan sangat setuju dengan perangkat pembelajaran yang disebar dan menyarankan agar perangkat pembelajaran yang telah dibuat sekiranya dapat dikembangkan untuk model pembelajaran yang lain atau pun dengan pengembangan selain 4D.

\section{KESIMPULAN}

Berdasarkan hasil penelitian yang telah dilakukan, dapat disimpulkan sebagai berikut:

1. Perangkat pembelajran dengan menggunakan strategi POE pada materi pokok asam basa untuk meningkatkan hasil belajar peserta didik yang dikembangkan telah memenuhi syarat validitas dengan nilai rata-rata validasi RPP 3,29 termasuk kategori valid, LKPD dengan nilai rata-rata 3,60 termasuk kategori sangat valid, dan BPD dengan nilai rata-rata 3,17 termasuk kategori valid, serta THB dengan nilai rata 3,73 yang termasuk kategori sangat valid.

2. Perangkat pembelajran dengan menggunakan strategi POE pada materi 
pokok asam basa untuk meningkatkan hasil belajar peserta didik yang dikembangkan sudah memenuhi kriteria praktis. Kategori keterlaksanaan perangkat pembelajaran terlaksana seluruhnya, yaitu dengan nilai rata-rata dari uji pengembangan sebesar 1,89 dengan reliabilitas $91,66 \%$.

3. Perangkat pembelajran dengan menggunakan strategi POE pada materi pokok asam basa untuk meningkatkan hasil belajar peserta didik yang dikembangkan telah memenuhi syarat efektifitas, dimana setelah dilakukan uji coba lapangan perangkat pembelajaran yang dikembangkan telah dapat mencapai tujuan pembelajaran yaitu meningkatkan hasil belajar peserta didik. Hal ini terlihat dari nilai rata-rata peserta didik 80,00 dengan kategori $\mathrm{N}$ Gain tinggi $62,86 \%$ terdapat 22 orang peserta didik.

\section{DAFTAR RUJUKAN}

Dimyati dan Mujiono. 2006. Belajar dan Pembelajaran. Jakarta: Rineka Cipta.

Farhana. 2016. Pengaruh Pembelajaran POE Terhadap Hasil Belajar Peserta Didik. Jakarta: Universitas Islam Negeri Syarif Hidayatullah.

Hobri. 2009. Metodologi Penelitian Pengembangan. Jakarta: Proyek DIA-BERMUTU Program Pendidikan Matematika FKIP Universitas Jember.

Ipek. 2010. Using POE strategy to investigate student teachers' understanding about the effect of substance type on solubility. Procedia Social and Behavioral Sciences, Vol. 2 No. 648-653 Tahun 2010.

Karamustafaoğlu, \& Mamlok-Naaman, R. 2015. Understanding Electrochemistry Concepts Using The Predict-Observe- Explain Strategy. Eurasia Journal Of Mathematics, Science \& Technology Education, 11(5), 923-936.
Http://Doi.Org/10.12973/Eurasia.20 $15.1364 \mathrm{a}$

Kibirige, I., J. Osodo, \& K. M. Tlala. 2014. The Effect Of Predict-ObserveExplain Strategy on Learners' Misconceptions about Dissolved Salts. Mediterranean Journal of Social Sciences, Vol 5 No. 4.

Meltzer, D. 2002. The Relationship between Mathematics Preparation and Conceptual Learning Gains in Physics. A possible, Hidden Variabel, in Diagnostic Pretest Score. Department of Physics and Astronomy. Iowa: Iowa State Universiy Ames.

Nurdin. 2007. Model Pembelajaran Matematika Untuk Menumbuhkan Kemampuan Metakognitif Untuk Menguasai Bahan Ajar. Surabaya: Unesa.

OECD. 2013. PISA 2012 Results: What Students Know and Can Do-Student Performance in Mathematics, Reading and Science (Volume i). [Online]. Tersedia: http://www.oecd.org/pisa/keyfindin gs/pisa-2012-results-volume-I.pdf.

Riduwan, N.G., dan Engkos, A.K. 2008. Cara Menggunakan dan Memaknai Analisis Jalur (Path Analysis). Bandung: Alfabeta.

Rusman. 2011. Pembelajaran Berbasis Teknologi Informasi dan Komunikasi. Jakarta: Rajawali Pers.

Thiagarajan, S. 1974. Instructional Development For Training Teacher of Expectional Children. Indiana University

Trianto. 2009. Mendesain Model Pembelajaran Inovatif, Progresif, Dan Kontekstual. Jakarta : Kencana Prenada Media Group

Warpala, Subagia, \& Suastra. 2010. Pengembangan Bahan Ajar Berbasis Kearifan Lokal Untuk Mata Pelajaran Sains Smp, 4(0362).

Warsono. \& Hariyanto. 2012. Pembelajaran Aktif Teori dan Assesmen. Bandung: PT Remaja 
Chemistry Education Review, Pendidikan Kimia PPs UNM, 2018, Vol.1, No.2 (115-124)

Rosdakarya.

Yupani, Garminah, \& Mahadewi. 2013.

Pengaruh Model Pembelajaran

Predict-Observe- Explain (Poe)

Berbantuan Materi Bermuatan

Kearifan Lokal Terhadap Hasil

Belajar. 